\title{
PENGARUH BAURAN PEMASARAN TERHADAP KEPUTUSAN PEMBELIAN PRODUK RM AYAM BAKAR WONG SOLO DI CIPETE
}

\author{
1*Wibowo, ${ }^{2}$ Dodi Ilham, ${ }^{3}$ Diah Asdiany \\ STIE Hidayatullah, Depok, Jawa Barat, Indonesia \\ 1,2Institut Agama Islam Negeri (IAIN) Palopo, Indonesia \\ wibowo@stiehidayatullah.ac.id
}

\begin{abstract}
Abstrak
Penelitian ini bertujuan untuk mengetahui pengaruh bauran pemasaran terhadap keputusan pembelian produk RM Ayam Bakar Wong Solo di Cipete. Metode yang digunakan adalah explanatory research dengan sampel sebanyak 96 responden. Teknik analisis menggunakan analisis statistik dengan pengujian regresi, korelasi, determinasi dan uji hipotesis. Hasil penelitian ini variabel bauran pemasaran diperoleh nilai rata-rata skor sebesar 3,473 dengan kriteria baik. Variabel keputusan pembelian diperoleh nilai ratarata skor sebesar 3,808 dengan kriteria baik. Bauran pemasaran berpengaruh positif dan signifikan terhadap keputusan pembelian dengan nilai persamaan regresi $\mathrm{Y}=13,525+$ $0,707 \mathrm{X}$, dan nilai koefisien korelasi 0,728 atau memiliki tingkat hubungan yang kuat dengan nilai determinasi 53,0\%. Uji hipotesis diperoleh signifikansi 0,000<0,05.
\end{abstract}

Kata Kunci: Bauran Pemasaran, Keputusan Pembelian.

\section{Abstract}

This study aims to determine the effect of the marketing mix on purchasing decisions of RM Ayam Bakar Wong Solo products in Cipete. The method used is explanatory research with a sample of 96 respondents. The analysis technique uses statistical analysis with regression testing, correlation, determination and hypothesis testing. The results of this study of the marketing mix variable obtained an average score of 3.473 with good criteria. The purchase decision variable obtained an average score of 3.808 with good criteria. The marketing mix has a positive and significant effect on purchasing decisions with the regression equation $Y=13.525+0.707 X$, and the correlation coefficient value of 0.728 or has a strong level of relationship with a determination value of $53.0 \%$. Hypothesis testing obtained a significance of $0.000<0.05$.

Keywords: Marketing Mix, Purchasing Decision. 


\section{PENDAHULUAN}

Persaingan antar perusahaan tentu saja tidak dapat dihindari dalam dunia bisnis. Perusahaan dituntut untuk dapat lebih inovatif dan kreatif dalam memasarkan produknya. Semakin banyaknya produk-produk baru yang terus bermunculan, beragamnya harga yang ditawarkan dan dapat dijangkau oleh konsumen, serta kegiatan promosi yang sangat gencar dilakukan yang terus diimbangi dengan dana distribusi yang besar. Perusahaan harus mempunyai pembaharuan dalam menyusun strategi dan memodifikasi strategi tersebut. Ini dikarenakan perusahaan ingin produknya menjadi yang terbaik bagi konsumen. Memodifikasi strategi secara modern merupakan salah satu konsep utama dalam bauran pemasaran. Bauran pemasaran terdiri dari segala sesuatu yang dapat dilakukan perusahaan untuk mempengaruhi permintaan produknya.

Perlu ada pertimbangan produk untuk dipasarkan oleh perusahaan, tanpa adanya pertimbangan produk dan tanpa prosedur manjemen untuk dikerjakan atau diselesaikan, menggunakan formula manajemen baru dengan memberikan iklan yang benar didalam kombinasi metode perdagangan, bentuk produk, harga, promosi dan metode penjualan, dan saran distribusi metode penjualan. Dari kombinasi kemungkinan didapatkan keuntungan dari persaingan perusahaan lain (Borden, 1984:2).

Bauran pemasaran merupakan konsep alat pemasaran untuk dapat mengembangkan strategi dengan terkendali yang dipadukan oleh perusahaan untuk dapat menarik konsumen yang sudah menjadi sasaran pasar. Sarana bauran pemasaran dikelompokkan menjadi empat kelompok besar yang disebut 4P pemasaran: produk (product), harga (price), tempat (place), dan promosi (promotion) (Kotler \& Armstrong, 2008:62). Konsumen dapat dirangsang dengan konsep yang mula-mula perusahaan harus dapat menawarkan barang atau jasa (produk) yang dibutuhkan oleh konsumen, perusahaan memutuskan biaya (harga) barang atau jasa disesuaikan dengan keadaan konsumen yang menjadi sasaran, setelah itu dapat mengetahui bagaimana ketersediaan wilayah (tempat) konsumen tersebut mendapatkan barang atau jasa yang ditawakan. Setelah memutuskan tiga hal tersebut maka perusahaan mulai merancang cara untuk dapat berkomunikasi dengan konsumen yang tujuan utamanya untuk membujuk konsumen tentang barang atau jasa yang ditawarkan (promosi)

Berdasarkan observasi yang dilakukan oleh peneliti, konsumen memiliki beberapa standar untuk menentukan produk apa yang akan dikonsumsi untuk memenuhi kebutuhannya. Keputusan yang dilakukan konsumen ini dapat dilihat dari beberapa faktor yang dibagi menjadi faktor internal dan faktor eksternal. Faktor internal adalah adanya kebutuhan yang wajib harus dipenuhi, sedangkan faktor eksternal seperti adanya presentasi penjualan yang menarik dari konsumen ke konsumen lainnya yang menyebabkan konsumen lain ingin mengkonsumsi produk tersebut, selain itu faktor-faktor lain yang ada pada produk tersebut juga menjadi pertimbangan yang akan mempengaruhi keputusan konsumen.

Rumah Makan Ayam Bakar Wong Solo merupakan rumah makan yang sudah lama eksistensinya di kota Cipete. Ditengah persaingan pemasaran produk rumah makan yang semakin kuat, maka RM Ayam Bakar Wong Solo mempunyai strategi pemasaran yang dapat membuat konsumen tertarik untuk dapat kembali lagi membeli atau mengkonsumsi produk dari RM Ayam Bakar Wong Solo di Cipete.

Berdasarkan pemaparan latar belakang tersebut, maka peneliti bermaksud melakukan penelitian yang bertujuan untuk mengetahui pengaruh yang signifikan bauran pemasaran terhadap keputusan pembelian produk RM Ayam Bakar Wong Solo Cipete. 


\section{METODE}

Populasi dalam penelitian ini berjumlah 96 responden konsumen produk RM Ayam Bakar Wong Solo di Cipete. Teknik pengambilan sampling dalam penelitian ini adalah sampel jenuh, dimana semua anggota populasi dijadikan sebagai sampel. Dengan demikian sampel dalam penelitian ini sampel yang digunakan berjumlah 96 responden. Jenis penelitian yang dipakai adalah asosiatif, dimana tujuannya adalah untuk mengetahui atau mencari keterhubungan antara variabel independen terhadap variabel dependennya. Dalam menganalisis data digunakan uji validitas, uji reliabilitas, analisis regresi linier sederhana, analisis koefisien korelasi, analisis koefisien determinasi dan pengujian hipotesis.

\section{HASIL DAN PEMBAHASAN}

\section{Analisis Deskriptif}

Pada pengujian ini digunakan untuk mengetahui skor minimum dan maksimum skor tertinggi, ratting score dan standar deviasi dari masing-masing variabel. Adapun hasilnya sebagai berikut:

Tabel 1. Hasil Analisis Descriptive Statistics

Descriptive Statistics

$\mathrm{N}$ Minimum Maximum Mean Std. Deviation

\begin{tabular}{|c|c|c|c|c|c|}
\hline Bauran pemasaran $(X)$ & 96 & 29 & 48 & 34.73 & 4.043 \\
\hline Keputusan pembelian (Y) & 96 & 29 & 49 & 38.08 & 3.927 \\
\hline Valid N (listwise) & 96 & & & & \\
\hline
\end{tabular}

Bauran pemasaran diperoleh varians minimum sebesar 29 dan varians maximum 48 dengan ratting score sebesar 3,473 dengan standar deviasi 4,043 . Skor ini termasuk pada rentang sakala 3,40 - 4,19 dengan kriteria baik atau setuju.

Keputusan pembelian diperoleh varians minimum sebesar 29 dan varians maximum 49 dengan ratting score sebesar 3,808 dengan standar deviasi 3,927 . Skor ini termasuk pada rentang sakala 3,40 - 4,19 dengan kriteria baik atau setuju.

Tabel 2. Hasil Pengujian Regresi Linier Sederhana.

Coefficients $^{\mathrm{a}}$

\begin{tabular}{lr|r|r|r|r} 
& \multicolumn{2}{c}{ Unstandardized Coefficients } & Standardized Coefficients & & \\
Model & $\mathrm{B}$ & Std. Error & Beta & $\mathrm{t}$ & Sig. \\
\hline 1 (Constant) & 13.525 & 2.401 & & 5.632 & .000 \\
\hline Bauran pemasaran $(\mathrm{X})$ & .707 & .069 & .728 & 10.295 & .000 \\
\hline
\end{tabular}

Berdasarkan hasil pengujian pada tabel di atas, diperoleh persamaan regresi $\mathrm{Y}=13,525+$ 0,707X. Dari persamaan tersebut dijelaskan sebagai berikut:

1) Konstanta sebesar 13,525 diartikan jika bauran pemasaran tidak ada, maka telah terdapat nilai

\section{Analisis Verifikatif}

Pada analisis ini dimaksudkan untuk mengetahui pengaruh variabel independen terhadap variabel dependen. Adapun hasil pengujian sebagai berikut:

\section{a. Analisis Regresi Linier Sederhana}

Uji regresi ini dimaksudkan untuk mengetahui perubahan variabel dependen jika variabel independen mengalami perubahan. Adapun hasil pengujiannya sebagai berikut: 
b. Analisis Koefisien Korelasi

Analisis koefisien korelasi dimaksudkan untuk mengetahui tingkat kekuatan hubungan dari

Tabel 3. Hasil Pengujian Koefisien Korelasi Bauran pemasaran Terhadap Keputusan pembelian.

\section{Correlations $^{b}$}

\begin{tabular}{llr|r} 
& & Bauran pemasaran $(X 1)$ & Keputusan pembelian (Y) \\
\hline Bauran pemasaran $(X)$ & Pearson Correlation & 1 & $.728^{* *}$ \\
\cline { 2 - 4 } & Sig. (2-tailed) & & .000 \\
\hline Keputusan pembelian $(Y)$ Pearson Correlation & $.728^{* *}$ & 1 \\
\cline { 2 - 4 } & Sig. (2-tailed) & .000 & \\
\hline
\end{tabular}

Berdasarkan hasil pengujian diperoleh nilai korelasi sebesar 0,728 artinya bauran pemasaran memiliki hubungan yang kuat terhadap keputusan pembelian. variabel independen terhadap variabel dependen. Adapun hasil pengujian sebagai berikut:

\section{c. Analisis Koefisien Determinasi}

Analisis koefisien determinasi dimaksudkan untuk mengetahui besarnya persentase pengaruh dari variabel independen terhadap variabel dependen. Adapun hasil pengujian sebagai berikut:

Tabel 4. Hasil Pengujian Koefisien Determinasi Bauran pemasaran Terhadap Keputusan pembelian.

Model Summary

\begin{tabular}{lr|r|r|r} 
Model & R & R Square & Adjusted R Square & Std. Error of the Estimate \\
\hline 1 & $.728^{\mathrm{a}}$ & .530 & .525 & 2.707 \\
\hline
\end{tabular}

artinya bauran pemasaran memiliki kontribusi pengaruh sebesar $53,0 \%$ terhadap keputusan pembelian, sedangkan sisanya sebesar $47,0 \%$ dipengaruhi oleh faktor lain yang tidak dilakukan penelitian.

\section{d. Uji Hipotesis}

Pengujian hipotesis dengan uji $\mathrm{t}$ digunakan untuk mengetahui hipotesis mana yang diterima.

Rumusan hipotesis: Terdapat pengaruh yang signifikan antara bauran pemasaran terhadap keputusan pembelian.

Tabel 5. Hasil Uji Hipotesis Bauran pemasaran Terhadap Keputusan pembelian.

Coefficients $^{\mathrm{a}}$

Unstandardized Coefficients Standardized Coefficients

\begin{tabular}{lr|r|r|r|r} 
Model & \multicolumn{1}{c|}{ B } & Std. Error & Beta & \multicolumn{1}{c}{ t } & Sig. \\
\hline 1 (Constant) & 13.525 & 2.401 & & 5.632 & .000 \\
\hline Bauran pemasaran $(X)$ & .707 & .069 & .728 & 10.295 & .000 \\
\hline
\end{tabular}

Berdasarkan hasil pengujian pada tabel di atas, diperoleh nilai $\mathrm{t}$ hitung $>\mathrm{t}$ tabel atau $(10,295>1,986)$, dengan demikian hipotesis yang diajukan bahwa terdapat pengaruh yang signifikan atara bauran pemasaran terhadap keputusan pembelian diterima.

\section{PEMBAHASAN HASIL PENELITIAN}

1. Kondisi Jawaban Responden Variabel Bauran pemasaran

Berdasarkan jawaban responden, variabel bauran pemasaran diperoleh ratting score sebesar 3,473 berada di rentang skala 3,40 - 4,19 dengan kriteria baik atau setuju. 
2. Kondisi Jawaban Responden Variabel Keputusan pembelian

Berdasarkan jawaban responden, variabel keputusan pembelian diperoleh ratting score sebesar 3,808 berada di rentang skala 3,40 - 4,19 dengan kriteria baik atau setuju.

3. Pengaruh Bauran pemasaran Terhadap Keputusan pembelian

Bauran pemasaran berpengaruh signifikan terhadap keputusan pembelian dengan persamaan regresi $Y$ $=13,525+0,707 \mathrm{X}$, nilai korelasi sebesar 0,728 atau memiliki hubungan yang kuat dengan kontribusi pengaruh sebesar $53,0 \%$. Pengujian hipotesis diperoleh nilai $\mathrm{t}$ hitung $>\mathrm{t}$ tabel atau $(10,295>$ 1,986). Dengan demikian hipotesis yang diajukan bahwa terdapat berpengaruh signifikan antara bauran pemasaran terhadap keputusan pembelian diterima.

\section{PENUTUP}

\section{Simpulan}

1. Variabel bauran pemasaran diperoleh ratting score sebesar 3,473 berada di rentang skala 3,40 - 4,19 dengan kriteria baik atau setuju.

2. Variabel keputusan pembelian diperoleh ratting score sebesar 3,808 berada di rentang skala 3,40 - 4,19 dengan kriteria baik atau setuju.

3. Bauran pemasaran berpengaruh signifikan terhadap keputusan pembelian dengan persamaan regresi $Y$ $=13,525+0,707 \mathrm{X}$, nilai korelasi sebesar 0,728 atau kuat dan kontribusi pengaruh sebesar $53,0 \%$ sedangkan sisanya sebesar $47,0 \%$ dipengaruhi faktor lain. Uji hipotesis diperoleh nilai $\mathrm{t}$ hitung $>\mathrm{t}$ tabel atau $(10,295>1,986)$.

\section{Saran}

1. Rumah makan Ayam Bakar Wong Solo Cipete harus lebih meningkatkan strateginya dalam melakukan kegiatan penjualan produk yang ditawarkan. Menggunakan pemikiran yang kreatif dengan mengembangkan sebuah produk yang akan ditawarkan kepada konsumen membuat perusahaan akan lebih menguntungkan, namun hal ini perlu diikuti dengan segala sesuatu yang dibutuhkan dan diinginkan oleh konsumen.

2. Perusahaan perlu mempertimbangkan seperti produk dengan tampilan desain yang berbeda dengan pesaing rumah makan yang lain dan bisa mewujudkan ciri khas, harga yang dapat dijangkau semua kalangan tidak hanya untuk keluarga saja, tempat dengan sarana parkir yang luas dan dengan sarana promosi yang lebih gencar karena komunikasi padaa saat ini sangat mudah dengan menggunakan media sosial yang semakin canggih dan mudah di akses masyarakat.

\section{DAFTAR PUSTAKA}

Abdullah, M (2014) Manajemen dan Evaluasi Penjualan produk, Yogyakarta: Penerbit Aswaja Pressindo.

Algifari. (2015). "Analisis Regresi untuk Bisnis dan Ekonomi". Yogyakarta: BPFE.

Arikunto, Suharsimi (2014). "Prosedur Penelitian Suatu Pendekatan Praktek". Jakarta: Rineka Cipta.

Bashu Swastha dan T. Handoko (2015) Manajemen Pemasaran Moderen, Yogyakarta: BPFE.

Basu Swastha Dharmmesta. (2014). Manajemen Pemasaran. BPFE: Yogyakarta. Buchari Alma. 2014. Manajemen pemasaran dan Pemasaran Jasa. Edisi Revisi.

Bilson Simamora (2016) Panduan Riset Prilaku Konsumen, Jakarta: PT. Gramedia Pustaka.

Fandy Tjiptono (2017), Serivce Quality and Satisfiation. Jakarta: Edisi tiga. Andi.

Freddy Rangkuti (2016) SStrategi Promosi Yang Kreatif, Edisi Pertama, Cetakan Pertama Jakarta: Gramedia Pustaka Utama.

Haque, MG., Munawaroh, Sunarsi, D., (2020). Analysis of SMEs Culinary Marketing Strategy During Covid 19 Pancemic: A Study at "Sate Bebek Cilegon" Resto in Cilegon, Banten. International Journal of Education, 
Information Technology, and Others. Vol.3. Issue 2

Imam Ghozali (2017). "Aplikasi Analisis Multivariate Dengan Program SPSS". Edisi Kelima. Semarang: Badan Penerbit Undip.

Jasmani, J. (2019). Pengaruh Product Development Dan Promotion Mix Terhadap Peningkatan Penjualan Yang Berdampak Pada Keunggulan Bersaing. Jurnal Ekonomi Efektif, 1(2). Jasmani, J. (2019). Pengaruh Promosi Dan Pengembangan Produk Terhadap Peningkatan Hasil Penjualan. Jurnal Semarak, 1(3).

Jasmani, J., \& Sunarsi, D. (2020). The Influence of Product Mix, Promotion Mix and Brand Image on Consumer Purchasing Decisions of Sari Roti Products in South Tangerang. PINISI Discretion Review, 1(1), 165-174.

Kharis, Ismu Fadli (2011). "Studi Mengenai Impulse Buying dalam Penjualan Online". Semarang : Skripsi Universitas Diponegoro

Kotler dan Amstrong (2017), Prinsip-prinsip Pemasaran. Edisi Kedua Belas". Jilid Satu. Jakarta: Erlangga.

Lupiyoadi (2016) Manajemen Pemasaran Jasa, Edisi 4, Jakarta: Salemba Empat.

Maddinsyah, A., Hidayat, D., Juhaeri, J., Susanto, D., \& Sunarsi, D. (2020). Desain Formulasi Dan Implementasi Bisnis Strategik Dengan Pendekatan Business Model Canvas (BMC) Terintegrasi Kerangka Integrated Performance Management System (IPMS) Pada Koperasi Asperindo. Inovasi, 7(2), 67-76.

Phipil Kotler dan Kevin Keller (2017) Manajemen Pemasaran, Edisi Kedua Belas, Jilid Satu, Jakarta: Erlangga.

Rao, Purba, (2012). "Measuring Consumer Perceptions Through Factor Analysis", The Asian.

Santoso, Singgih (2015). "Menguasai Statistik Multivariat". Jakarta: PT Elex Media Komputindo.
Sarwani, S., Akbar, I. R. ., Handoko, A. L. ., \& Ilham, D. . (2020). Pengaruh Pelatihan dan Motivasi terhadap Produktivitas Kerja Karyawan pada PT. Lion Mentari Airlines Bandara Internasional Soekarno Hatta Cengkareng. Jurnal Ilmu Komputer Dan Bisnis, 11(2a), 91-100. https://doi.org/10.47927/jikb.v11i2a .24

Sugiyono (2017), "Metode Penelitian Administrasi : dilengkapi dengan Metode $R \mathcal{E} D$ ". Bandung: Alfabeta.

Suhartanto (2014). "Metode Riset Pemasaran". Bandung: Alfabeta

Sunarsi, D. (2020). Pengaruh Bauran Pemasaran Dan Kualitas Pelayanan Terhadap Kepuasan Konsumen Pada Giant Dept Store Cabang BSD Tangerang. E-Mabis: Jurnal Ekonomi Manajemen dan Bisnis, 21(1).

T Triyadi, U Ahidin, J Jasmani - Jurnal Manajemen, Bisnis dan Organisasi (JUMBO), 2019. Pengaruh Promosi Dan Kualitas Pelayanan Terhadap Kepuasan Pelanggan Pada PT. Surya Karya Prima Di Jakarta.

Ukkas, I., \& Iksan, M. (2017). Empowering Business Group Peanut Tenteng. Proceeding International Conference on Natural and Social Science (ICONSS) 2017, 1(1), Article 1.https://journal.uncp.ac.id/inde x.php/iconss/article/view/540

Yonata, H. . ., Setiawan, P., Santamoko, R. ., Ilham, D. ., \& Asdiany, D. . (2020). Pengaruh Kualitas Pelayanan dan Kepuasan Konsumen terhadap Loyalitas Pelanggan pada PT. Satria Antaran Prima. Jurnal Ilmu Komputer Dan Bisnis, 11(2), 2502-2514. https://doi.org/10.47927/jikb.v11i2. 14

Yusuf, A., \& Sunarsi, D. (2020). The Effect of Promotion and Price on Purchase Decisions. Almana: Jurnal Manajemen dan Bisnis, 4(2), 272-279. 